\title{
SYSTEM OF CONTINUOUS TRAINING OF ELEMENTARY SCHOOL TEACHERS TO WORK WITH THE GIFTED STUDENTS: EXPERIMENTAL RESEARCH
}

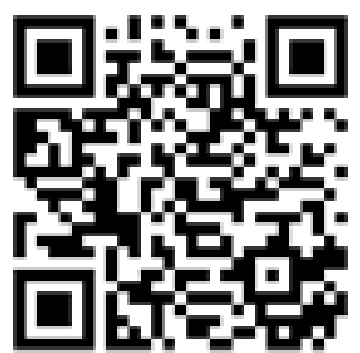

To cite this article:
Iryna Gavrysh, Dr. Sc., Prof.

Professor, Department of Theory and Methodics of Teaching Natural-Mathematical Disciplines in Preschool, Primary and Special Education,

H. S. Skovoroda Kharkiv National Pedagogical University

Kharkiv, Ukraine

irina.gavrysh@gmail.com

http://orcid.org/0000-0002-0173-1855

Victoria Ushmarova, Dr. Sc., Prof.

Head, Department of Primary and Professional Education,

H. S. Skovoroda Kharkiv National Pedagogical University

Kharkiv, Ukraine

victoria.uschmarova@gmail.com

https://orcid.org/0000-0003-1394-3596

Oleksandra Kholtobina, PhD, Ass. Prof.

Associate Professor, Department of Theory and Technology

of Pre-school Education and Art Disciplines,

H. S. Skovoroda Kharkiv National Pedagogical University

Kharkiv, Ukraine

olexandra.holtobina@gmail.com

https://orcid.org/0000-0002-2155-7129

Gavrysh, I., Ushmarova, V., \& Kholtobina, O. (2021). System of continuous training of elementary school teachers to work with the gifted students: experimental research. Education: Modern Discourses, (4), 76-89.

https://doi.org/10.37472/2617-3107-2021-4-08

\begin{abstract}
The study investigates the preparation of elementary school teachers for working with gifted students, and the process of its formation in the system of continuous pedagogical education. The methodological, theoretical and methodological principles of the study are presented. The study theoretically substantiated the main principles of the elementary school teachers' preparation to work with gifted students. Core components are demonstrated to be motivational, cognitive, activity, reflexive and personal. The author's scientific-methodical system of forming readiness elementary school teachers to work with gifted students in the conditions of continuous pedagogical education are presented The stages of its realization are determined and the effectiveness of implementation of the said system is experimentally proved. The criteria, indicators and levels of preparedness of elementary school teachers to work with gifted students are clarified.
\end{abstract}

Keywords: continuous pedagogical education; elementary school; formation; giftedness; readiness; scientific-methodical system; teacher. 


\section{INTRODUCTION}

The education of the national elite is of fundamental importance to any society, and a competent teacher is the key to its success. That is why the school needs specialists with a unique blend of personal and professional qualities, prepared for work with gifted students.

This is emphasized in the documents of international organizations, including UNESCO, UNICEF, the World Council for Gifted and Talented Children, the European Council for High Ability, the National Association for Gifted Children (National Association for Gifted Children) etc.

Having realized the right of the individual to the free development of abilities and talents, and recognizing the formation of a socially active, creative personality as one of the factors required for economic development and competitiveness of Ukraine, the state educational policy aims at reforming the education system in the interests of successful self-realization of the individual in life.

Fundamentals of the state educational policy in the sphere of work with gifted children and youth are covered in the Law of Ukraine "On Education" (2017), Concept "New Ukrainian School" (2016), Decree of the President of Ukraine "On Measures to Develop a System for Identifying and Supporting Gifted and Talented Children and Youth" (2010), the Decree of the Cabinet of Ministers of Ukraine "On the Establishment of the Gifted Child Institute" (2007), the Joint Resolution of the Collegium of the Ministry of Education and Science of Ukraine and the Presidium of the Academy of Sciences of Ukraine "On Ways to Improve the Activities of the Small Academies Ukrainian students and academic societies as centres of formation of scientific elite of Ukraine" (2003) and others.

Particularly urgent is the problem of forming teacher readiness to work with gifted elementary school students. According to the latest world research in the field of learning and development of gifted children (Freeman, 2017; Gagne, 2011; Renzulli, 2016 etc.), potentially gifted children make up not $1-3 \%$, as it was accepted in the 19th-20th centuries, but up to $15-$ $30 \%$ of the total age sample. At the same time, the role of the teacher in the development of the personality of the gifted child is recognised to be the leading element in the early school age, since external influences at the initial stages of the development of giftedness are much more important than the effects that are carried out during the later life (Laine, 2016). In addition, given the age characteristics, younger school age is particularly sensitive to the development of educational motivation, cognitive activity, intelligence and creativity of students. This is of paramount importance when it comes to the gifted child (Laine, 2016; Leites, 2003; Sękowski, 2015).

This allowed us to recognize the problem of studying the theoretical and methodological principles of forming the readiness of elementary school teachers to work with gifted students as a priority for research and understanding.

\section{LITERATURE REVIEW}

The Ukrainian and foreign scholars have accumulated considerable scientific-theoretical and practical-methodological achievements on the problem of identification, education and upbringing of gifted children and young people. In particular, a wide palette of educational technologies that contribute to the development of their talents has been developed (Antonova, 2016; Bogoyavlenskaya, 2013; Kashapov, 2012; Leites, 2003; Renzulli, 2016; Savenkov, 2006; Shadrikov, 2019 and others).

A separate cluster of activity consists of studies by domestic and foreign scholars in the field of educational comparative investigations, aimed at studying the world pedagogical experience of education and upbringing of gifted children and young people. 
In pedagogical science, the issues of preparing teachers to work with gifted students in the systems of higher and postgraduate pedagogical education are sufficiently developed. These questions are addressed in the researches of Y. Klimeniuk and others some specific issues in preparing future teachers to work with gifted students, including elementary school teachers, have been embodied (Klimeniuk, 2009).

However, the problem of teacher readiness to work with gifted students cannot be considered separately in pedagogical institutions of higher education and institutions of postgraduate pedagogical education. The dynamic of social change, the modernization of the list of teacher's personal and professional competences, the recognition of the axiological priority of the $21^{\text {st }}$ century of lifelong education, crystallize the challenges of creating a continuous system of teacher training for educating the intellectual elite of the nation. Some aspects of continuous training of teachers to work with gifted students are outlined in the research of O. Vashchuk, V. Demchenko and others (Vashchuk, 2014; Demchenko, 2009).

At the same time, the existing practice of preparing elementary school teachers to work with gifted students is largely unsystematic, since this phenomenon has not yet been the subject of structured research by the Ukrainian and foreign scholars.

Synthesis of research results and analysis of traditions and innovative processes in pedagogical education give grounds to formulate a fundamental contradiction between the modern awareness of the role of the intellectual elite of the nation in the development of a highly developed, competitive state, and the lack of theoretically justifiable systemization.

The purpose of the paper is to present the results of experimental verification of the scientific and methodological system for forming the readiness of elementary school teachers to work with gifted students, in the conditions of continuous pedagogical education.

\section{THEORETICAL FOUNDATIONS AND METHODS OF RESEARCH}

Challenges in forming the readiness of elementary school teachers to work with gifted students were actively included in the thematic field of domestic scientific and pedagogical research at the end of the twentieth century. This process was accelerated by a new wave of research. In evaluating the formation of the readiness of elementary school teachers to work with gifted students, in the system of continuous pedagogical education, we consider the purpose and result of appropriate training in higher and postgraduate pedagogical education.

In this study, the formation of the readiness of elementary school teachers to work with gifted students in the system of continuous pedagogical education is considered to require the development of elementary school teachers with the skill-sets needed to work with gifted students: motivational and value orientations, knowledge, skills, professional and personal higher education. We look to improve these competences in the system of postgraduate pedagogical education, on the basis of continuity and perspective in teacher development (Shadrykov, 2019).

Elementary school teacher readiness to work with gifted students is defined as an integrative personal education containing motivational, cognitive, activity and reflexivepersonal components. For working with gifted elementary school students, these are conditions and regulators of successful professional and pedagogical activity.

Based on the analysis of the theory of motivation (Ilyin, 2006; Shadrykov, 2019 etc.) and the theory of activity (L. Vygotsky, P. Halperin, O. Leontiev, S. Rubinstein, etc.), the feasibility of forming motives is substantiated by attitudes and value orientations, as a process of internalization of the goals of professional activity aimed at developing the giftedness of young schoolchildren.

The decisive factor in the readiness of elementary school teachers to work with gifted students is the systematic knowledge (Khomich, 2014 etc.), which determines the expediency 
of forming methodological, theoretical and methodological knowledge as elements of the cognitive component of the readiness to be studied. Based on the analysis of scientific views (Brigandi, 2019) on the essence and structure of pedagogical skills, the expediency of forming gnostic, design, constructive, organizational, communicative skills, which are components of practical readiness of elementary school teachers to work with gifted students, is substantiated. It has been established that the ability of a elementary school teacher to reflect critically on his or her professional activity, and professionally important personal qualities, should be tailored to the professional requirements for the content of the elementary school teacher's work with gifted students.

Forming the readiness of elementary school teachers to work with gifted students is ensured by the implementation of a holistic, multi-level, multicomponent scientific and methodological system (Fig. 1) as an organic unity of the target conceptual, substantive-procedural, controlcorrecting and evaluation-successive components on perspectives.

The strategic goal of the system is defined. It is the readiness of the elementary school teacher to work with gifted students, as a prerequisite for successful professional activity in the field of diagnostics and education of gifted students. The stated purpose is specified as a system of tactical and operational goals (Fig. 2).

The scientific and methodological system covers the links, levels and stages of forming the readiness of elementary school teachers to work with gifted students, in the conditions of continuous pedagogical education as a whole cycle.

The process of formation of the investigated readiness (the formative stage of the pedagogical experiment) had an extensive system of measures and actions towards forming the readiness of future elementary school teachers and practitioners to work with gifted students. These covered the university and postgraduate links in continuous pedagogical education. The step-by-step process of formation of the investigated readiness was ensured by the implementation of a multicomponent scientific and methodological system in the university (bachelor, master's) and postgraduate (course, inter-course preparation, self-education) links in continuous pedagogical education. in each step, the content, tactical and strategic goals were specified.

Continuous process of forming the readiness of future elementary school teachers to work with gifted students began in the system of higher pedagogical education and included preparation in bachelor's and master's degree according to propedeutical (1 year), theoretical and practical (2-4 courses), and the general course. The end-to-end curriculum for forming the readiness of future elementary school teachers to work with gifted students was developed and tested Teaching and methodological kits were created to ensure its implementation. The process of forming the readiness of future elementary school teachers to work with gifted students was implemented using a set of traditional, problem-seeking, interactive (debates of Karl Popper, "Press", “Silent Discussion”, “Roundabout”, portfolio, etc.), role playing games, pedagogical ring, etc.), imitation (imitation-game modelling of professional activity, training of professional development, developmental professional psychodiagnostics, etc.) methods, as well as traditional (lectures, seminars, practical classes, consultations, independent, individual work, etc.) and innovative ("Professional Development School", pedagogical performance, mini-conferences, group and individual development and protection of creative projects, etc.) forms.

At the propedeutic stage, the purpose of which was to form a general understanding of the structure, content, nature and specificity of future professional activity of elementary school teachers, awareness of the purpose and formation of motivation to work with gifted students, the main tasks of forming the readiness of future elementary school teachers to work with students were carried out within the framework of teaching the normative disciplines 


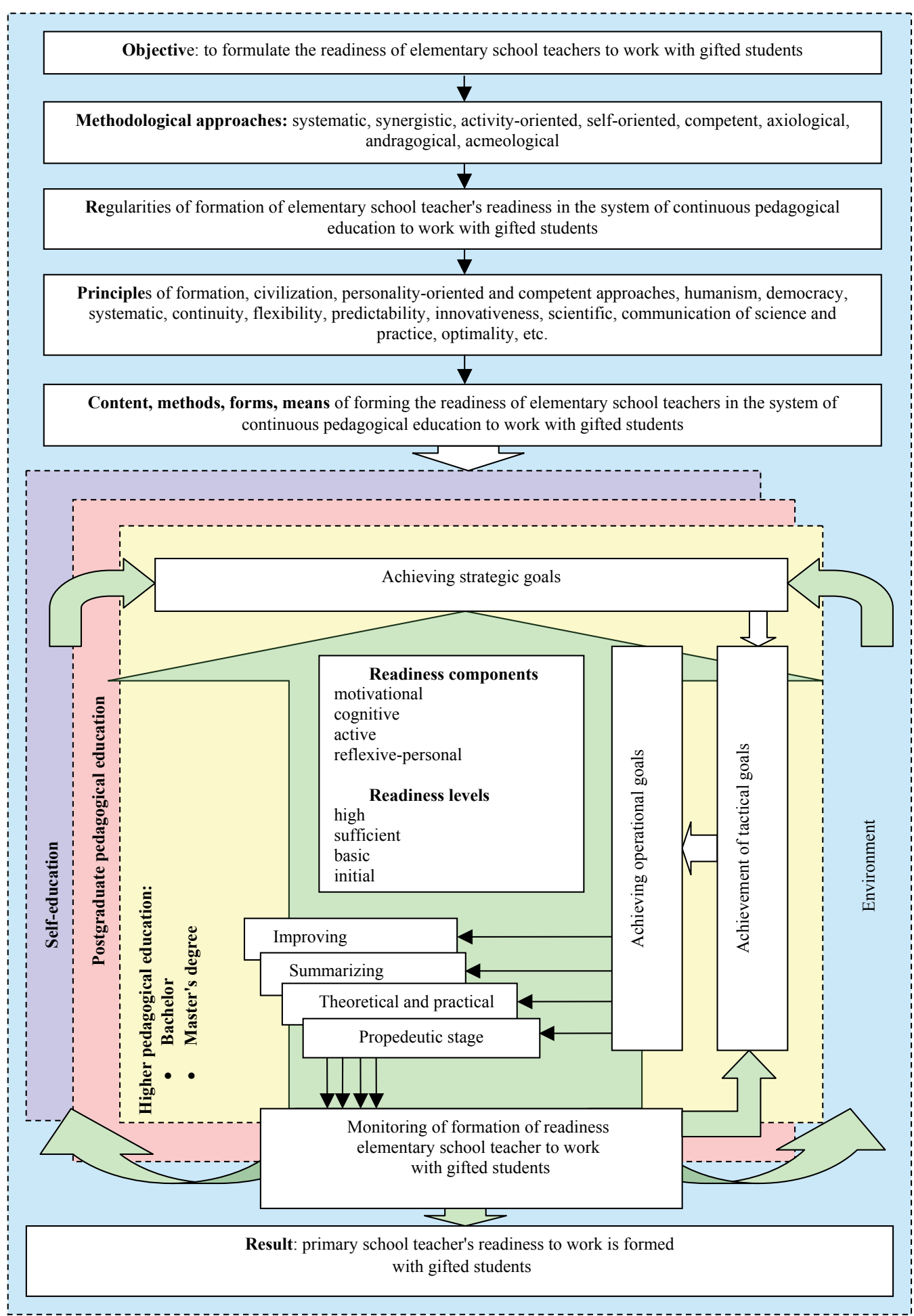

Fig. 1.

Information model of scientific and methodological system of readiness formation in elementary school teachers to work with gifted students, under conditions of continuous pedagogical education

Source: Designed by authors. 

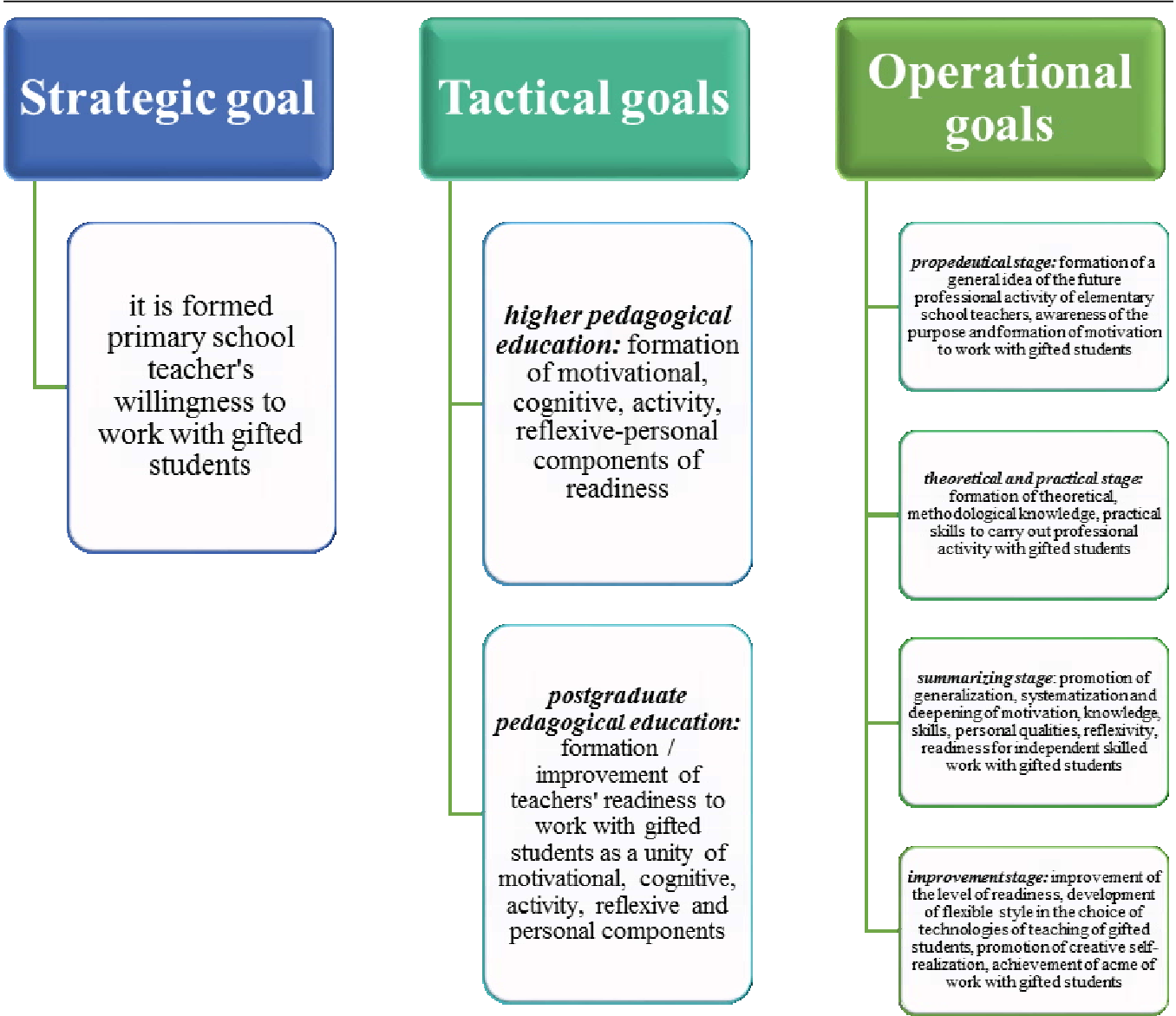

Fig. 2.

An information model of the hierarchy of goals for forming the readiness of elementary school teachers to work with gifted students in the system of continuous pedagogical education

Source: Designed by authors.

of the curriculum: "Introduction to the specialty", "Psychology", "Theory and methodology of education", and a continuous course in which students practice in out-of-class educational activities (creative work contest "A gifted teacher - gifted students").

The purpose of the theoretical and practical stage was to develop students' knowledge of pedagogy and psychology of giftedness in the study of educational disciplines, and to form the experience of their practical application in the process of pedagogical practice. This stage is important because the fourth year completes basic vocational education and, accordingly, a certain stage of forming the readiness of future elementary school teachers to work with gifted students, requiring the formation of their own views, assessments, attitudes and approaches to the specified sphere of pedagogical activity. The fulfilment of the tasks of the stage was carried out during the study of disciplines "Didactics", "Age Psychology", "Fundamentals of psychodiagnostics", "Pedagogical skills", "Pedagogical technologies in elementary school"; methods of teaching primary school subjects; organization of effective pedagogical practice; formation of students' objective assessment and self-assessment of readiness to work with gifted students. The curriculum was supplemented by topics with relevant content for working with gifted students, and suggested guidelines for students and teachers.

The activity of "The School of Professional Development" was started. This is an innovative 
organizational model of interaction of experienced teachers with elementary school teachers, teachers and students of the Faculty of Primary Education. This form of teacher education for future elementary school teachers was introduced by us on the basis of learning from the positive experience of its use as a form of innovative learning in the process of reforming the professional development of future teachers and practitioners in the United States, initiated by the Holmes Group. We have also developed educational and methodological support for classes at "The School of Professional Development" (plan of work of the School of Professional Development, individual student curriculum, basic notes of lectures).

Forming the readiness of future elementary school teachers to work with gifted students also involved engaging students in research work. Thus, for the purpose of course work on pedagogy, a list of topics related to the problems of work with gifted children was proposed, in particular, "Children's giftedness as a psychological and pedagogical problem', "Personal characteristics of gifted children", "Development of general giftedness in elementary school", "Educational and educational interaction with gifted children", "Giftedness: nature, signs, types", "Methods and forms of development of academic talent of younger students", "Development of gifted younger students via the project activities", "The use of modern educational technology in teaching gifted elementary school students", "The problem of giftedness in the context of national projects in education" and so on.

Forming the readiness of future elementary school teachers to work with gifted students was facilitated by participation in extracurricular activities, in particular in the pedagogical skills contest. One of the tasks was a pedagogical performance on the topic "A gifted teacher gifted students".

Students actively gained experience working with gifted students during their teaching practice. Pedagogical practice is a systematic factor of future teacher's professional preparation, a leading factor of his professional self-development, formation of individual creative style of professional activity, and improvement of pedagogical skill of future teachers. It is pedagogical practice that combines students' theoretical readiness with future professional activity and facilitates their experience in the field of diagnosis and education of gifted students. On this basis, the programs of practice are coordinated so that they are as close as possible to future pedagogical activities with gifted students. The programme of industrial pedagogical practice provided for:

1) studying and analysis by students of the plan of work of the school with gifted pupils of elementary grades;

2) participation in procedures for diagnosing giftedness;

3) participation in designing the individual educational trajectory of the gifted student;

4) participation in creating a development environment for gifted elementary school students, etc.

The summarizing stage was dedicated to systematization and extension of methodological, theoretical and practical knowledge of future teachers in elementary schools working with gifted students. These changes promote the mastering of the ability to perform professional actions with gifted students of the elementary school and support the development of motivation, reflexiveness and personal professional skills that are important in working with gifted students of the elementary school.

First, the tasks of this stage were realized during the course named "Working with gifted students". The educational information about giftedness, its kinds, index, diagnostic technologies, methods, and preferred forms of studying by gifted students were presented in the given course proposed by the curriculum. We worked out the methodical supplementary for learning of the course - the learning and working programs of the course, synopsis of the lectures, materials for practical works, tasks for independent learning, supplementary for 
progress and final monitoring of learning achievements, the list of literature and informational resources were synthesized and prepared.

Within the course "The peculiarities of working of elementary school teachers with parents", students learned the system of knowledge as useful for pedagogical interaction with a family of a clever student.

The preparation on the master's degree level was dedicated to creation of the conditions for translation of the questions concerning of giftedness and working with gifted students, into the sphere of scientific research during the performance of scientific and research projects.

The master's degree students were guided to consider as the topic of scientific researches "The comparative analysis of content, methods and forms of preparation of teachers to the working with gifted students in Europe", "Teachers' preparation for work with gifted students in the USA", etc. The master's degrees students were gaining the ability to create the formation of researching readiness during the learning of pedagogical courses, such as: to write synopsis of the traditional and interactive lectures, practical works on the topics "The peculiarities of bringing gifted students up", "The strategies of choice in the concept of education for gifted students", "Modern technologies of gifted students' education", "The forms of organization of gifted students' studying activity", "The methods of giftedness' diagnostic", etc. That contributed to understanding, by students, of the concept, forms and methods of development of elementary school teachers' professional readiness to work with gifted students.

The meaningful process of continuous formation of readiness of elementary school teachers for work with gifted students continued during the improving stage within the postgraduate pedagogical education.

On the basis of studying scientists' views (Savchenko, 2010 etc.) it was proved that scientific - methodological work in comparison with the course qualification elements is an efficient way to deal with the problems that appear in the teacher's work. Having considered the tendencies of modern transformations in the national system of education, the expediency of performing elementary school teachers' preparation for the working with gifted students specifically via the process of scientific - methodological work was established.

According to the principles of scientific - methodological work as realized in the period of professional advancement, especially actualization, individualization, succession and continuity; scientific quality and simplicity; practical directions and system, we created "Scientific and semantic plan for the courses for teachers of special classes of the elementary school who work according to the scientific and educational project "The Intellect of Ukraine" (144 hours). It was approved by the Order of Ministry of education and science of Ukraine No. 898 as of 28.09.2009. It includes 3 modules - social and humanitarian, professional and diagnostic and analytical. It is delivered thus:

- One-week summer courses of professional advancement for teachers of the project classes developed in the scientific and educational project "The Intellect of Ukraine" - 14hour lectures (Philosophy of education. Axiological imperatives of national politics in the sphere of education. The concept of "New Ukrainian School", "The pedagogy of partnership and the ways of its realization in scientific and educational project "The Intellect of Ukraine", "Innovation educational technologies in working with gifted students of elementary school", "Theoretical and methodical basis of teaching subjects "Learning of reading and writing", "The Ukrainian language", "The literary reading" according to the program "The Intellect of Ukraine", "Organization of the work with pupils' parents of project classes", "Keeping and strengthening health of participants of educational and bringing up process" etc. dedicated to the formation of the cognitive component of readiness to work with gifted students; 52 hours of practical works (group coach sessions "Personally oriented approach to the education of gifted students", "Formation of the key competencies on the basis of working approach", methodical 
practical lessons "The formation of knowledge, abilities and skills of gifted students on the basis of step by step formation of mental activities", "Goal setting in the education of gifted students: taxonomy of educational aims of B. Bloom", workshops "The formation of the skills of efficient reading", "The development of educational processes"); 10 hours of laboratory lessons (situational seminar "The creation of individual and educational approach for a gifted student", case studies "Critical situations from school life of gifted students"; a training that is aimed on the correction self-conception of teachers with the use of techniques of self-development, improvement of the technique of the professional communication, pedagogical reflection and empathy, the ability to listen and to hear, optimal time division at the lesson, etc.).

- Via monthly one-day scientific and practical seminars for the increasing of the professional teachers' competence level during the visiting and discussing of the lessons in project classes;

- In individual study during the school year, aimed at creation of collective and individual projects on the chosen topic "Giftedness and modelling problem of the educational society in the concept of New Ukrainian School", "Basic theories of giftedness", "General and specializing giftedness", "The problem of genotypic and social determination in development of giftedness", "The evolution of learning theories of gifted students", "Academic giftedness as social and pedagogic notion", "The leadership of giftedness in the context of the modern theories of elites", etc.) - they are viewed as creative credit works (Bachynska, 2013).

Subject thematic schedule is basic for EG 2, EG 3, EG 4, but the concept, methods and forms of studying had their peculiarities for each group.

Based on systematization of the results of scientific researches, the meaningful peculiarities of the process of formation of teachers' readiness to the working with gifted students in the experimental groups EG 2, EG 3, EG 4 were identified.

Considering the results of the pioneer investigation and ascertaining stage of the experiment, it was established that for teachers having less than 3 years in their career, the absence of practical working experience with gifted students is the most important problem. There is uncertainty in the precision of studying approaches to work with gifted students and experiential difficulties in interaction with gifted students. The result is disappointment in the occupation. The problem of integration a elementary school teacher to the pedagogical collective of the school is also important.

With the reference to this identified skills gap, the complex of scientific and methodological events was implemented. It was aimed at perceiving the understanding by elementary school teachers of their professional and personal skills, their advantages, and determining individual motivating factors to the working with gifted students. The objectives were increasing work satisfaction; understanding the goals and tasks which a teacher can face in working with gifted students; and simplifying of group work in the pedagogical community. The main studying method on the courses was coaching. Learners joined the work in coach groups to consult with an experienced teacher/coach. Methods such as portfolio, role and business games were used. The basic forms of scientific work dedicated to practical adaptation of a elementary school teacher to the occupation were visiting and discussing the lessons conducted by experienced teachers; individual coach sessions; and situational seminars where analysis was performed, discussing and solving simulated and real situations that appear during the diagnosis and education of gifted students.

During the pilot investigation and ascertaining stage, it was established that the biggest problem for teachers who work from 3 to 10 years is an insufficient level of their preparation for innovative professional activity with gifted students. This lack has a negative impact on the formation level of cognitive, reflexive-private and activity preparation components for work with gifted students. That's why the following tasks of professional advancement E3 were 
defined among the most significant: increasing of the knowledge of teachers of using innovative teaching technologies with gifted students; the perfection of skills for objective evaluation of innovative educational technologies, to define the expedience of their usage in teachers' own professional activity; and to effectively involve educational technologies into the teaching and educational process.

In order to solve the defined tasks, different methods and forms of professional advancement are used. The leading methods are brainstorming, discussion, and round table. The leading forms are methodical practicum and master-class. The teachers of such category were attracted also as coaches to work in "The school of professional development" with the students of higher educational establishments (Ushmarova, 2016).

It was clarified during the constant stage, that teachers having more than 10 years' experience feel that they are not able to work within the concept of modern education in respect of changing the teacher's position and understanding new roles and functions of professional and pedagogic activity. Teachers mentioned that they do not have enough flexibility of pedagogic awareness, and/or felt a lack of ability to work in self-subject space in situations of uncertainty, readiness to improvise and employ dialogue conversation style.

In the social and humanitarian module of the curriculum of the courses for EG4, we offered a section providing a valuable basis of systematic changes - topics "The philosophy of education. Axiological imperatives of national politic in the sphere of education. The concept of New Ukrainian School", "The pedagogy of partnership and the ways of its realization in the scientific and pedagogic project "The Intellect of Ukraine". These topics help teachers to orientate their understanding of vast changes, understand their full value and sense of position that demonstrates the attitude and preparedness to work with gifted students.

We also found that for teachers who have worked more than ten years, the problem of using informational communicative technologies is very significant. Therefore, special attention was paid to the teachers' formation of the skills of Multimedia used in teaching of gifted students. During the laboratory lessons teachers gained knowledge and skills of productive Multimedia, using basic applied programs as Microsoft Office, Windows Movie Maker, and other technical means of studying in teaching gifted students. In the monthly one-day scientific and practical seminars teachers visited and discussed the lessons in project classes that were conducted using Multimedia. During the individual study, teachers worked out their own Multimedia to the 14 project classes (video fragments, virtual excursions, interactive models. Videos, multimedia presentation, slide-show, etc.).

Among the methods that were used while working with this group of participants we should mention the method of projects, case-method; and among the forms - pedagogical lounge, situational seminar, methodical festival.

\section{MAIN RESULTS}

In order to test the hypothesis of the study, in validation of the scientific and methodological system of forming the readiness of elementary school teachers in the system of continuous pedagogical education to work with gifted students, a pedagogical experiment was conducted.

The multifactoriality of the experiment led to the division of experimental participants into two types of control (CG) and experimental (EG) groups. Their participants belonged to different categories (university students, elementary school teachers). EG 1 includes students who studied in the specialty 013 "Primary education". The teachers are grouped into three experimental groups (EG 2, EG 3, EG 4). The EG 2 group included teachers with experience in general education from 1 to 3 years; to EG group 3 - teachers whose pedagogical experience is 3-10 years; to EG group 4 - teachers with more than 10 years of experience. This division 
into experimental groups was justified by the fact that the participants of each group had to choose methods of pedagogical action relevant to their level of preparedness to work with gifted students. In control groups (CG 1, CG 2, CG 3, CG 4), the preparation of elementary school teachers to work with gifted students was carried out according to traditional methods (Ushmarova, 2016).

At the ascertaining stage of the pedagogical experiment, the initial level of willingness of future primary and secondary teachers to work with gifted students was determined. The statistical grouping of the experiment participants was carried out at four levels: high, sufficient, basic, initial. To establish the level of readiness of the participants in the experiment, a set of complementary methods was used, which provided sufficient experimental material: testing, questioning, observation and analysis of students' activities during pedagogical practices and qualified teachers during attending and discussing lessons, analysis of student participation discussions, defence of individual and group projects, essays, abstracts, term papers and more.

Generalization of the results of the ascertainment stage of the experiment was carried out using K. Pearson's criterion $\chi^{2}$, which proved the null hypothesis that the level of willingness to work with gifted students in the participants of the experimental and control groups did not differ significantly. The results of the statement stage of the experiment confirmed the need for purposeful work in forming the readiness of elementary school teachers to work with gifted students. At the control stage of the pedagogical experiment, the dynamics of indicators in the levels of willingness to work with gifted students from the participants of the experiment were revealed, the static hypothesis of the study and the generalization of its results were tested. It was found that the number of participants in the experiment with a sufficient level of readiness to work with gifted students increased by $16.5 \%$ in EG and $6.0 \%$ in CG. The increase in the number of teachers with a basic level is $17.7 \%$ and $22.2 \%$, respectively; with a high level $-8.4 \%$ and $3.8 \%$. The dynamics of the initial level of study readiness was $-42.6 \%$ in EG and $-32.0 \%$ in CG.

Let us present the distribution of the participants of the experiment according to the levels of readiness to work with gifted students in the combined experimental and control groups (Table 1., Fig. 3).

Table 1

\section{Distribution of experiment participants by levels of readiness to work with gifted students (control stage)}

\begin{tabular}{|c|c|c|c|c|c|c|c|c|}
\hline \multirow{3}{*}{$\begin{array}{c}\text { Components } \\
\text { of } \\
\text { readiness }\end{array}$} & \multicolumn{8}{|c|}{ Readiness levels (\%) } \\
\hline & \multicolumn{2}{|c|}{ high } & \multicolumn{2}{|c|}{ sufficient } & \multicolumn{2}{|c|}{ basic } & \multicolumn{2}{|c|}{ initial } \\
\hline & $\mathrm{EG}$ & CG & EG & CG & $\mathrm{EG}$ & CG & $\mathrm{EG}$ & CG \\
\hline motivational & 7.35 & 5.03 & 23.65 & 10.58 & 28.43 & 34.13 & 40.58 & 50.28 \\
\hline cognitive & 7.63 & 3.03 & 23.53 & 12.55 & 26.9 & 33.13 & 41.95 & 51.3 \\
\hline active & 8.93 & 3.45 & 24.4 & 11.8 & 29.13 & 35.8 & 37.55 & 48.95 \\
\hline reflexive-personal & 9.58 & 3.6 & 23 & 13.78 & 28.83 & 34.8 & 38.6 & 47.83 \\
\hline integrated & 8.37 & 3.78 & 23.64 & 12.18 & 28.32 & 34.46 & 39.67 & 49.59 \\
\hline
\end{tabular}




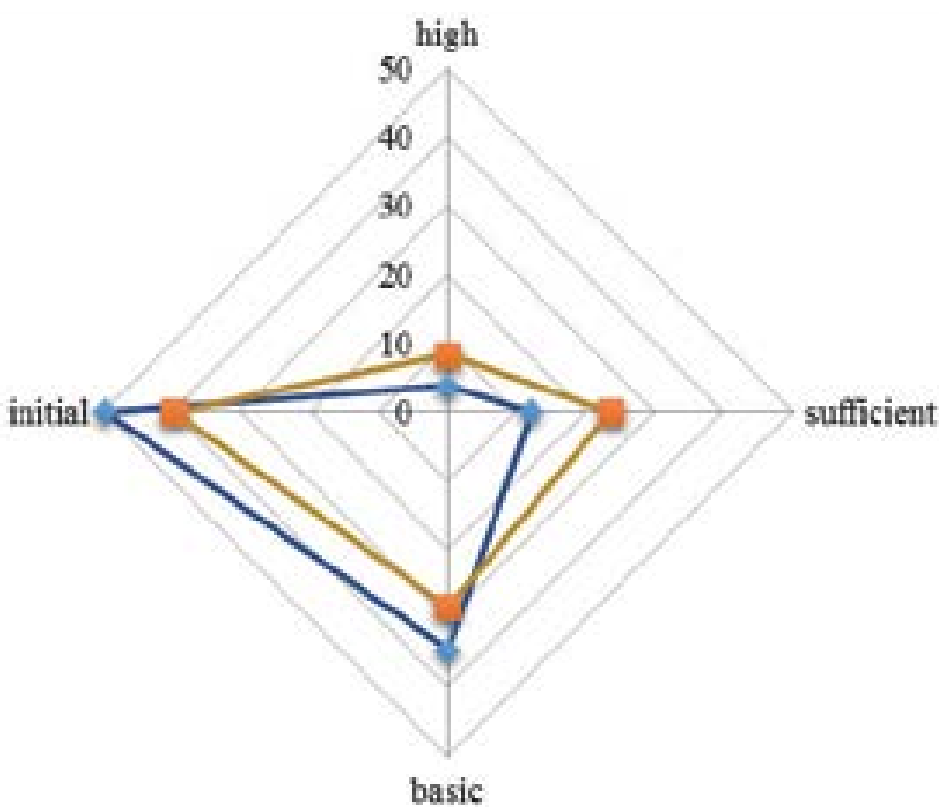

Fig. 3.

Diagram of distribution of participants in the control phase of the experiment by levels of readiness to work with gifted students (control phase)

Source: Designed by authors.

At the control stage of the experiment, using the K. Pearson criterion $\chi^{2}$ again tested the null hypothesis that the distribution of participants of the experiment into groups and categories is an independent value, that is, there is no difference between the levels of formation of components of willingness to work with gifted students in quantitative indicators in experiments and control groups. Alternative hypothesis: the division into categories depends on the division into groups, that is, the difference between the levels of willingness to work with gifted students by quantitative indicators in the experimental and control groups at the control stage of the experiment. Table 2 was compiled to calculate $\chi_{\text {emp }}^{2}$.

Table 2

Calculating the value of $\chi_{\text {emp }}^{2}$ for the control step of pedagogical experiment

\begin{tabular}{|l|c|c|c|c|c|}
\hline \multicolumn{1}{|c|}{$\begin{array}{c}\text { Readiness level } \\
\text { (category) }\end{array}$} & $\begin{array}{c}\text { Empirical } \\
\text { frequency } n_{i}\end{array}$ & $\begin{array}{c}\text { Theoretical } \\
\text { frequency } n_{i}^{\prime}\end{array}$ & $n_{i}-n_{i}^{\prime}$ & $\left(n_{i}-n_{i}^{\prime}\right)^{2}$ & $\left(n_{i}-n_{i}^{\prime}\right)^{2} / n_{i}^{\prime}$ \\
\hline High & 8.4 & 3.8 & 4.6 & 21.16 & 5.57 \\
\hline Sufficient & 23.6 & 12.2 & 11.4 & 129.96 & 10.65 \\
\hline Basic & 28.3 & 34.4 & -6.1 & 37.21 & 1.08 \\
\hline Initial & 39.7 & 49.6 & -9.9 & 98.01 & 1.98 \\
\hline Total & $\mathbf{1 0 0}$ & $\mathbf{1 0 0}$ & - & - & $\mathbf{1 9 . 2 8}$ \\
\hline
\end{tabular}

According to the table we can conclude: $\chi_{\text {emp }}^{2}=19.28$. The number of statistical categories has changed, so the number of degrees of freedom: $r=4-1=3$. According to the tables of 
critical values of the criterion $\chi^{2}$ with the significance level $a=0.05$, we find $\chi_{\mathrm{cr}}^{2}=7.8 \cdot \chi_{\mathrm{emp}}^{2}>\chi_{\mathrm{cr}}^{2}$ $(19.28>7.8)$. Therefore, the null hypothesis is rejected and the alternative is accepted, that the groups under consideration are significantly different.

Thus, at the ascertaining stage, the condition of the experimental and control groups is almost the same, and after the forming experiment, the data differ. It can be concluded that the positive changes are caused by the use of scientific and methodological system of forming teachers' readiness to work with gifted students.

\section{CONCLUSIONS}

The results of the experimental study confirmed that the developed scientific and methodological system allows balancing of the content of the gradual process of forming the readiness of elementary school teachers to work with gifted students, at the university, postgraduate, and using self-educational units of continuous pedagogical education. This balancing helps to eliminate the gap between education and learning, science and practice; it gives structure to make effective use of the scientific, educational and laboratory facilities of higher and postgraduate teacher education institutions: it provides a route to engage teachers and students in professional work in the field of diagnostics and education of gifted students; it supports timely and qualitative diagnosis of, and adjustment of the preparation process to the individual needs of the teacher; above all, it is clearly demonstrated to increase the capacity of elementary school teachers to work with gifted students.

It is proved that the use of the author's scientific and methodological system makes it possible to form motivational, cognitive, activity and reflexive-personal components of the teacher's readiness, as well as to ensure the continuity of his professional and personal development in the field of diagnostics and education of gifted students.

\section{REFERENCES}

Antonova, O. Ye. (2016). Kontseptualni teoretychni polozhennia ta pidkhody do vyvchennia pryrody obdarovanosti. In Akmedosiahnennia naukovtsiv Zhytomyrskoi naukovopedahohichnoi shkoly (pp. 71-102). Vyd-vo ZhDU im. I. Franka.

Bachynska, Ye., Ushmarova V., Sederevichene, A. (2013). Pidhotovka vchyteliv do roboty v 1-4 klasakh, pratsiuiuchykh za vseukrainskym naukovo-pedahohichnym proektom «Intelekt Ukrainy». Ridna shkola, 10, 69-74.

Bohoiavlenskaia, D. B. (2013). Odarennost: pryroda y dyahnostyka. ANO «TsNPRO».

Brigandi, C. B., Gilson, C. M., \& Miller, M. (2019). Professional Development and Differentiated Instruction in an Elementary School Pullout Program: A Gifted Education Case Study. Journal for the Education of the Gifted, 42(4), 362-395. https://doi.org/10.1177/0162353219874418

Vashchuk O. V. (2014). Formuvannia hotovnosti vchyteliv pryrodnychykh dystsyplin do rozvytku akademichnoi obdarovanosti starshoklasnykiv na zasadakh intehratyvnoho pidkhodu. [Avtoref. dys. kand. ped. nauk]. ZhDU im. I. Franka.

Freeman, J., Tourón, J. (2017). Gifted Education in Europe: Implications for policymakers and educators. In S.I. Pfeiffer (Ed.), APA Handbook on Giftedness and Talent (pp. 55-70). American Psychological Association (APA). https://doi.org/10.1037/0000038-004

Gagné, F. (2011). Academic talent development and the equity issue in gifted education. Talent Development and Excellence, 3, 3-32.

Havrysh, I., Kyrylenko, S. (2013). Innovatsiini osvitni proekty - kroky do svitovykh standartiv osvity (naukovo-pedahohichnyi proekt «Intelekt Ukrainy»). Ridna shkola, 10, 3-8. 
Demchenko V. V. (2009). Problemy profesiinoi hotovnosti pedahohichnykh kadriv do roboty z obdarovanymy shkoliaramy. Nova pedahohichna dumka, 2, 32-41.

Ylyn, E. P. (2006). Motyvatsyia y motyvy. Pyter.

Kashapov, M. M., Dudyreva, N. V. (2012). Professyonalno vazhnye kachestva pedahoha v rabote s odarennymy detmy. Vestnyk Yaroslavskoho hosudarstvennoho unyversyteta ym. P. H. Demydova, 4, 81-85.

Klymeniuk, Yu. M. (2009). Pidhotovka maibutnoho vchytelia do rozvytku intelektualnoi obdarovanosti uchniv pochatkovoi shkoly [Avtoref. dys. kand. ped. nauk]. ZhDU im. I. Franka.

Laine, S., Kuusisto, E., \& Tirri, K. (2016). Finnish teachers' conceptions of giftedness. Journal for the Education of the Gifted, 39(2), 151-167. https://doi.org/10.1177/0162353216640936

Leites, N. S. (2003). Vozrastnaia odarennost y yndyvydualnue razlychyia. NPO «MODEK».

Renzulli, J. (2016). The Three-Ring Conception of Giftedness: A Developmental Model For Promoting Creative Productivity. In Reflections On Gifted Education (pp. 55-86). Prufrock Press.

Savenkov, A. Y. (2006). Odarennyi rebenok doma i v shkole. U-Faktoryia.

Savchenko, O. Ya. (2010). Yakist pochatkovoi osvity: sutnist i chynnyky vplyvu. Naukovyi visnyk Mykolaivskoho derzhavnoho universytetu imeni V. O. Sukhomlynskoho, 1 (28), 36-50.

Sękowski, A.E., \& Łubianka, B. (2015). Education of gifted students in Europe. Gifted Education International, 31, 73-90. https://doi.org/10.1177/0261429413486579

Ushmarova, V. V. (2016). Naukovo-metodychna systema neperervnoho formuvannia hotovnosti vchyteliv pochatkovoi shkoly do roboty z obdarovanymy uchniamy. Pedahohika tapsykholohiia (pp. 241-250). Vydavets Rozhko S. H. http://oaji.net/articles/2016/1054-1470986208.pdf

Khomych, L. O. (2014). Aksiolohichni osnovy zmistu navchannia i vykhovannia maibutnikh vchyteliv. Vyshcha osvita Ukrainy, 3, 89-93.

Shadrykov, V. D. (2019). K novoi psykholohycheskoi teoryy sposobnostei y odarennosty. Psykholohycheskyi zhurnal, 2, 15-26. https://ras.jes.su/psy/s020595920002981-5-1 